\title{
From hardship to scholarship
}

\section{Maria Gallardo-Williams}

\author{
While there is much of the last two years we may wish to forget, it is \\ imperative that we share our pandemic chemistry teaching experiences.
}

There was a time that we have already romanticized in our collective memories, the idyllic pre-COVID era. A time where educators were free to choose their path, where the creation of online teaching and learning materials was entirely optional. As a chemistry lab instructor I am allowed to say that we might have been the smuggest of them all, proclaiming that chemistry labs were the final frontier for online education. The few brave souls that attempted to suggest that online chemistry labs might be valuable were usually met with a reminder that we

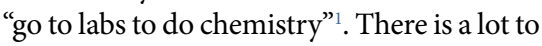
unpack in such a statement, but here are two great reads ${ }^{2,3}$ on rethinking labs. As in all good fairy tales, a formidable foe was right around the corner, ready to teach us a lesson. In our case the villain was virus-sized but mighty. It came first quietly, gradually and then all at once. And it made us do the unthinkable: close our physical doors and move our courses online.

\section{\&f the problems you solved have transferable applicability}

I remember exactly where I was when I learned that the university was closing its doors and that we were expected to pivot to fully online offerings. (Note that pivot is a word that has lost all meaning during the COVID-19 pandemic, but it will forever retain its power to trigger educators. I would like to formally petition for the removal of this problematic word from our lexicon.) We received the email from the upper administration during a meeting of our graduate recruiting committee. A hush fell over the room, followed by deep sighs and disbelief. Surely we could survive a short disruption? No doubt we would be back in person in just a couple of weeks. Is it any wonder that we were so naive? There was no precedent for such a large-scale educational disruption. We didn't know it at the time, but the COVID-19 pandemic would bring in-person instruction to a standstill all over the world, with very few exceptions. That day in the spring of 2020 changed everything for all of us. We couldn't go to labs, but we were still expected to do chemistry.

After the sheer panic of the first week subsided, we all got busy in our own unique ways. The range of responses was astounding. In my own department at North Carolina State University I saw five lab instructors come up with five different ways to teach labs online. Our lectures were not far behind. What we couldn't imagine had happened: our labs and classrooms were closed and we didn't know when we would be able to reopen them. We had to keep going, in the absence of all we knew, and we did. On a much larger scale, chemistry instructors all over the world created, improvised, and MacGyvered lectures, lab experiments, experiences, and simulations. A comprehensive review of laboratory learning in chemistry ${ }^{4}$ during the pandemic suggests that at least 91 relevant articles were published in 2020, but that number of publications barely hints at the

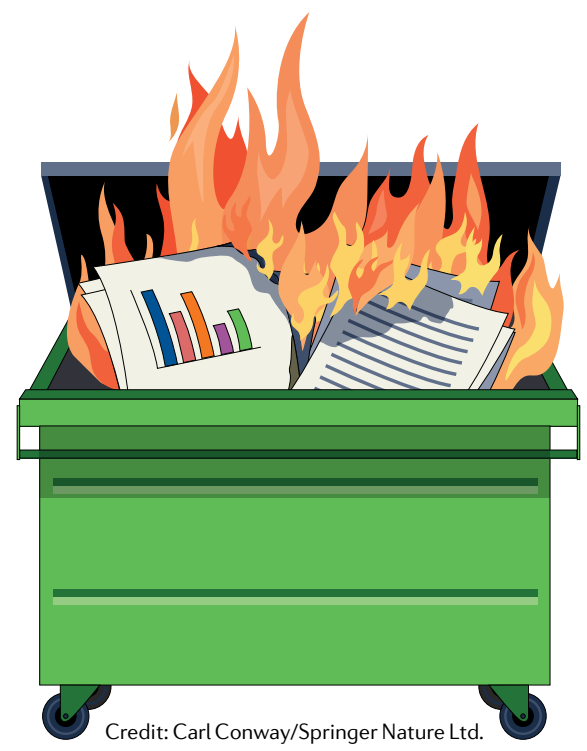

scale of the worldwide effort that took place. We all came up with ways to overcome the distance imposed by the COVID-19 threat, and what our next chapter looks like is up to us.

We are not $\mathrm{OK}^{5}$. All of us have just experienced and continue to experience one of the most severe disruptions to public life in over a hundred years. Our work, family, and social lives have been upended by the events of the last year and a half. Many of us have experienced losses that we are still grieving and will continue to grieve. Everything has changed, and yet we have managed to continue forging ahead with our jobs. In our academic environment, we all have struggled to find ways to meet the needs of our students and to continue our research endeavours, but it has taken a toll on all of us. We spent some time waiting for things to go back to normal, only to end up accepting that this is our new normal. This might not be our last pandemic. We could be affected by fires, rising sea levels, or violent storms, all of which will also effectively result in either temporary or extended closures of our universities. Given that is the case, we would all benefit from scholarly contributions to the literature detailing the adaptations and changes that we have made to our chemistry courses in order to adjust to online delivery. The last two years may have been a dumpster fire, but we shouldn't necessarily allow it to burn everything we've learned along the way.

There is value in sharing our pedagogical experiences, our teaching journey in these troubled times. The scholarship of teaching and learning literature needs to reflect the transformative work that took place during this time ${ }^{6}$. I would like you to think about the changes that you made to adapt your course to remote online delivery, and consider sharing some of those changes with the larger education community. Maybe you don't think that others will learn from it, but there is a need to know what others have done, or we will be doomed to independently reinvent the wheel over and over again? I was fortunate enough to have a set of online organic chemistry lab resources that were completed in the fall of 2019 . The social distancing imposed by the pandemic became our trial by fire. All obstacles to teaching labs online were forgotten as we scrambled to stay on track, and I found that there was 


\section{IN THE CLASSROOM}

a need in the community to learn from our experiences ${ }^{8}$.

Consider sharing the pedagogical lessons learned while teaching during the pandemic. Your research question, the problems you solved have transferable applicability. The methods you used to overcome your particular problem has the potential to help others. And your student outcomes, whether positive or negative, have value as we complete our picture of what it was like to teach during the pandemic. Don't let those lessons go to waste. We have lost enough already.
Maria Gallardo-Williams iD

Department of Chemistry, and SoTL Faculty Fellow, Office for Faculty Excellence, North Carolina State University, Raleigh, NC, USA.

e-mail:mtgallar@ncsu.edu

https://doi.org/10.1038/s41570-021-00349-3

1. Seery, M. K. Establishing the laboratory as the place to learn how to do chemistry. J. Chem. Educ. 97, 1511-1514 (2020)

2. Saggiomo, V. \& Velders, A. H. Experiments@home Nat. Rev. Chem. 5, 365-366 (2021).

3. Bretz, S. L. Evidence for the Importance of laboratory courses. J. Chem. Educ. 96, 193-195 (2019).

4. Kelley, E. W. LAB theory, HLAB pedagogy, and review of laboratory learning in chemistry during the COVID-19 pandemic. J. Chem. Educ. 98, 2496-2517 (2021).
5. Klein, J. Is the pandemic stressing you out? You're not alone. UC Health Today (24 September 2020); https://www.uchealth.org/today/dealing-withpandemic-stress-you-are-not-alone/.

6. Cox, M. D. Sharing your pandemic reaching and learning as the scholarship of teaching and learning. The Scholarly Teacher (15 September 2021);

https://www.scholarlyteacher.com/post/sharing-yourpandemic-teaching-and-learning-as-the-scholarshipof-teaching-and-learning.

7. Cruz, L. E. \& Grodziak, E. M. SoTL under stress: rethinking teaching and learning scholarship during a global pandemic. Teach. Learn. Inq. 9, 3-12 (2021).

8. Dunnagan, C. L. \& Gallardo-Williams, M. T Overcoming physical separation during COVID-19 using virtual reality in organic chemistry laboratories. J. Chem. Educ. 97, 3060-3063 (2020).

Competing interest

The author declares no competing interests. 